\title{
Karakteristik Asma pada Pasien Anak yang Rawat Inap Di RS Prof.R.D Kandouw Malalayang, Manado
}

\author{
Audrey M. I. Wahani \\ Bagian Ilmu Kesehatan Anak, Fakultas Kedokteran Universitas Sam Ratulangi/BLU. RSU. Prof. Dr. \\ R.D. Kandou, Manado
}

\begin{abstract}
Latar belakang. Asma merupakan salah satu penyakit respiratorik kronis yang paling sering dijumpai pada anak dengan angka rawat inap yang tinggi. Diagnosis masih sulit ditegakkan karena gambaran klinis asma yang bervariasi.

Tujuan. Mengetahui karakteristik pasien asma yang dirawat inap di BLU. RSU. Prof. Dr. R.D. Kandou Manado sejak Januari 2007 sampai dengan Desember 2008.

Metode. Penelitian retrospektif di Bagian Anak BLU. RSU. Prof. Dr. R.D. Kandou, Manado sejak Januari 2007 sampai dengan Desember 2008. Data diambil dari catatan rekam medik pasien anak yang dirawat inap dengan asma. Dicatat pada formulir untuk dipisahkan berdasarkan data demografik, diagnosis klinis dan pemeriksaan penunjang.

Hasil. Didapatkan 70 pasien yang didiagnosis dengan asma berdasarkan data rekam medik dalam periode yang diteliti, 55 pasien memiliki data yang lengkap, terdiri atas $29(52 \%)$ laki-laki, dengan usia rata-rata 5,4 tahun. Status gizi bervariasi, malnutrisi $(29,1 \%)$, gizi baik $(63,6 \%)$ dan gizi lebih $(7,3 \%)$. Lama perawatan rata-rata 4,0 hari. Hasil penemuan laboratorium menunjukkan $80 \%$ terdapat leukositosis. Diagnosis terbanyak adalah asma episodik sedang $(78,2 \%)$

Kesimpulan. Berdasarkan penelitian ini, asma terbanyak pada anak laki-laki. Status gizi pada umumnya baik dan terdapat leukositosis pada kebanyakan hasil pemeriksaan laboratorium. Asma episodik sedang adalah diagnosis yang paling banyak dijumpai. Sari Pediatri 2011;13(4):280-4.
\end{abstract}

Kata kunci: asma, karakteristik, diagnosis

\footnotetext{
Alamat korespondensi:

Dr. Audrey Wahani, SpA. Bagian Ilmu Kesehatan Anak FK UNSRAT/ RSU Prof. Dr. R. D. Kandou, Manado. Telepon : (0431)821652;Fax : (0431)859091; Email : audrey_wahani@yahoo.co.id
}

A

sma merupakan kelainan yang kompleks, dengan banyak faktor berperan dalam patogenesisnya. Oleh karena itu, tidak sederhana yang memuaskan semua pihak. ${ }^{1}$ Para perumus Konsensus Nasional Asma Anak 2002, 
mendefinisikan asma sebagai mengi berulang dan/atau batuk persisten dengan karakteristik sebagai berikut: timbul secara episodik, cenderung pada malam/dini hari (nokturnal), musiman, setelah aktifitas fisik serta adanya riwayat asma atau atopi lainnya pada pasien dan/atau keluarga. ${ }^{2}$

Asma merupakan penyakit respiratorik kronis yang paling sering dijumpai pada anak. ${ }^{3}$ Prevalensi asma meningkat dari waktu ke waktu baik di negara maju maupun negara sedang berkembang. Peningkatan tersebut diduga berkaitan dengan pola hidup yang berubah dan peran faktor lingkungan terutama polusi baik indoor maupun outdoor. ${ }^{4}$ Jumlah prevalensi asma di seluruh dunia diperkirakan 7,2\% (10\% pada anakanak) dan bervariasi antara negara. Prevalensi Asma di Indonesia berdasarkan penelitian pada tahun 2002 pada anak usia 13-14 tahun adalah 6-7\%. ${ }^{3}$

Prevalensi asma bervariasi dalam berbagai penelitian di seluruh dunia, antara lain dipengaruhi oleh definisi asma yang digunakan oleh peneliti dan metode dalam melaksanakan penelitian., ${ }^{5,6}$ Penelitian yang didapat dengan menggunakan kuesioner umumnya lebih rendah dari pada prevalensi yang diperoleh dalam penelitian klinik. ${ }^{6}$ Faktor lain yang mempengaruhi adalah keadaan geografis dan lingkungan serta ras. ${ }^{5,6}$ Prevalensi asma pada anak berkisar antara $2-30 \%$. Di Indonesia prevalensi asma pada anak sekitar $10 \%$ pada usia sekolah dasar, ${ }^{7}$ dan sekitar 6,5\% pada usia sekolah menengah pertama. ${ }^{8}$ Penyakit ini dapat timbul pada semua usia meskipun paling banyak pada anak. Asma dapat bersifat ringan dan tidak mengganggu aktivitas, akan tetapi dapat bersifat menetap dan mengganggu aktivitas bahkan kegiatan harian. ${ }^{3}$

Pedoman nasional asma anak di dalam batasan operasionalnya menyepakatinya kecurigaan asma apabila anak menunjukkan gejala batuk dan/atau mengi yang timbul secara episodik, cenderung pada malam hari/dini hari (nokturnal), musiman, setelah aktivitas fisik, serta adanya riwayat asma dan atopi pada pasien atau keluarganya. ${ }^{8}$ Diagnosis asma kadang-kadang masih sulit ditegakkan, karena gambaran klinis asma yang bervariasi dari pasien ke pasien. Bervariasinya gambaran klinis tersebut mengakibatkan banyak anak mendapatkan penanganan yang tidak rasional, tidak mendapat pencegahan dengan baik sehingga penyakit dapat berlanjut ke keadaan yang lebih gawat. ${ }^{8}$

Patogenesis asma berkembang dengan pesat. Pada awal 60-an, bronkokonstriksi merupakan dasar patogenesis asma, kemudian pada 70-an berkembang menjadi proses inflamasi kronis, sedangkan tahun 90an selain inflamasi juga disertai adanya remodelling. ${ }^{9,10}$ Berkembangnya patogenesis tersebut berdampak pada tata laksana asma secara mendasar, sehingga berbagai upaya telah dilakukan untuk mengatasi asma. Pada awalnya pengobatan hanya diarahkan untuk mengatasi bronkokonstriksi dengan pemberian bronkodilator, kemudian berkembang dengan antiinflamasi. Pada saat ini upaya pengobatan asma selain dengan antiinflamasi, juga harus dapat mencegah terjadinya remodeling. ${ }^{8}$

Klasifikasi asma sangat diperlukan karena berhubungan dengan tata laksana lanjutan (jangka panjang). GINA membagi asma menjadi 4 klasifikasi yaitu asma intermiten, asma persisten ringan, asma persisten sedang, dan asma persisten berat. ${ }^{4}$ Berbeda dengan GINA, PNAA membagi asma menjadi 3 yaitu asma episodik ringan, asma episodik sedang, dan asma persisten. Dasar pembagian ini karena pada asma anak kejadian episodik lebih sering dibanding persisten (kronisitas). Dasar pembagian atau klasifikasi asma pada anak adalah frekuensi serangan, lamanya serangan, aktivitas diluar serangan dan beberapa pemeriksaan penunjang. ${ }^{4}$

Tata laksana asma anak dibagi menjadi beberapa hal yaitu tata laksana komunikasi, informasi, dan edukasi (KIE) pada pasien dan keluarganya, penghindaran terhadap faktor pencetus, dan medikamentosa. ${ }^{4,8}$ Tata laksana asma dibagi menjadi 2 kelompok yaitu tata laksana pada saat serangan asma (eksaserbasi akut) atau aspek akut dan tata laksana jangka panjang (aspek kronis). Pada asma episodik sering dan asma persisten, selain penanganan pada saat serangan, diperlukan obat pengendali (controller) yang diberikan sebagai pencegahan terhadap serangan asma. ${ }^{8}$ Penatalaksanaan asma pada anak bertujuan untuk mencegah terjadinya serangan asma seminimal mungkin sehingga memungkinkan anak dapat tumbuh dan berkembang secara optimal sesuai dengan usianya. Serangan asma biasanya mencerminkan kegagalan pencegahan asma, kegagalan tata laksana asma jangka panjang dan kegagalan penghindaran dari faktor pencetus. ${ }^{7}$

Penelitian ini dilakukan dengan tujuan untuk mendeskripsikan karakteristik, status gizi, lama hari rawat diagnosis pasien anak dengan asma bronkial di ruang perawatan anak BLU RSUP Prof. R. D. Kandou, Manado. 


\section{Metode}

Penelitian ini dilakukan dengan analisis deskriptif secara retrospektif dari Januari 2007 sampai Desember 2008 yang diambil dari data rekam medis pasien asma bronkial yang dirawat di ruang perawatan anak BLU RSUP Prof. R. D. Kandou, Manado. Data yang diambil kemudian dianalisis secara komputerisasi menggunakan program SPSS 17,0. Pasien seluruhnya berjumlah 70 orang, 15 pasien di antaranya dieklusi karena data tidak lengkap, dan 55 pasien diambil sebagai sampel dalam penelitian.

Asma bronkial pada anak didefinisikan sebagai gejala batuk dan/atau mengi yang timbul secara episodik, cenderung pada malam hari/dini hari (nokturnal), musiman, setelah aktivitas fisik, serta adanya riwayat asma dan atopi pada pasien atau keluarganya.

\section{Hasil}

Dari data yang diperoleh sejak Januari 2007-Desember 2008 di ruang perawatan anak BLU Prof. Dr. R. D. Kandou, Manado diperoleh data pasien dengan diagnosis asma bronkial 55 pasien. Dari 55 pasien diperoleh jumlah kasus terbanyak terutama pada usia 5-9 tahun $(58,1 \%)$, jenis kelamin laki-laki $(52,5 \%)$, status gizi pasien kebanyakan gizi baik $(63,4 \%)$. Pasien umumya terdiagnosis dengan asma bronkial episodik jarang sebanyak 43 pasien $(78,18 \%)$, dengan lama hari rawat umumnya 3 hari $(25,4 \%)$.

Pada Gambar 1 menunjukkan jenis kelamin pasien yang dirawat dengan asma yang paling banyak adalah laki-laki sebanyak 29 pasien (52,5\%).
Pada Gambar 2 menunjukkan status gizi pasien yang dirawat dengan asma yang paling banyak adalah gizi baik, yaitu sebanyak 35 pasien $(63,4 \%)$.

Pada Gambar 3 menunjukkan lamanya hari rawat pasien dengan asma yang terbanyak adalah 3 hari, yaitu

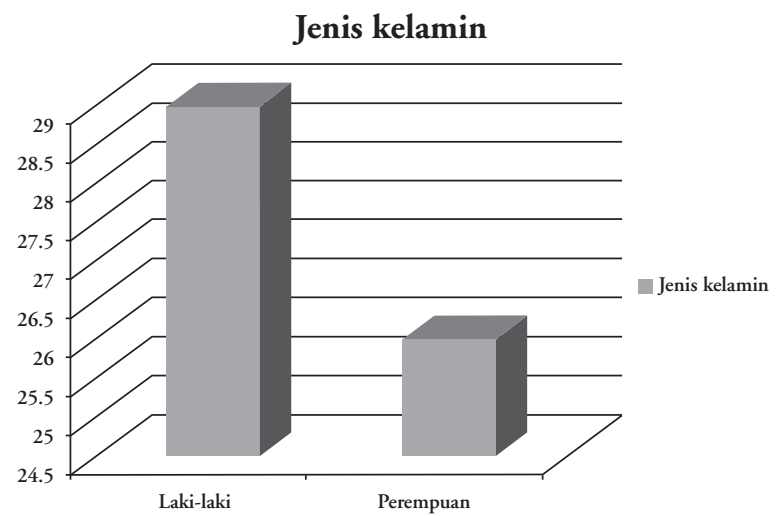

Gambar 1. Karakteristik pasien berdasarkan jenis kelamin

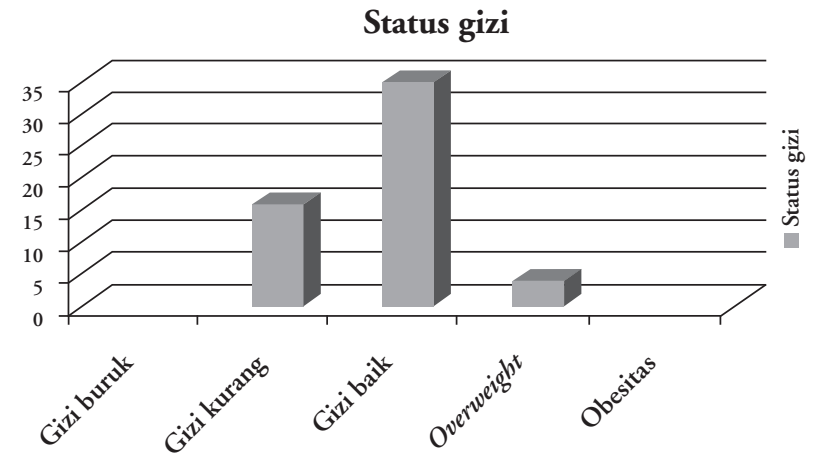

Gambar 2. Karakteristik pasien berdasarkan status gizi ( $Z$ score $\mathrm{WHO}$ )

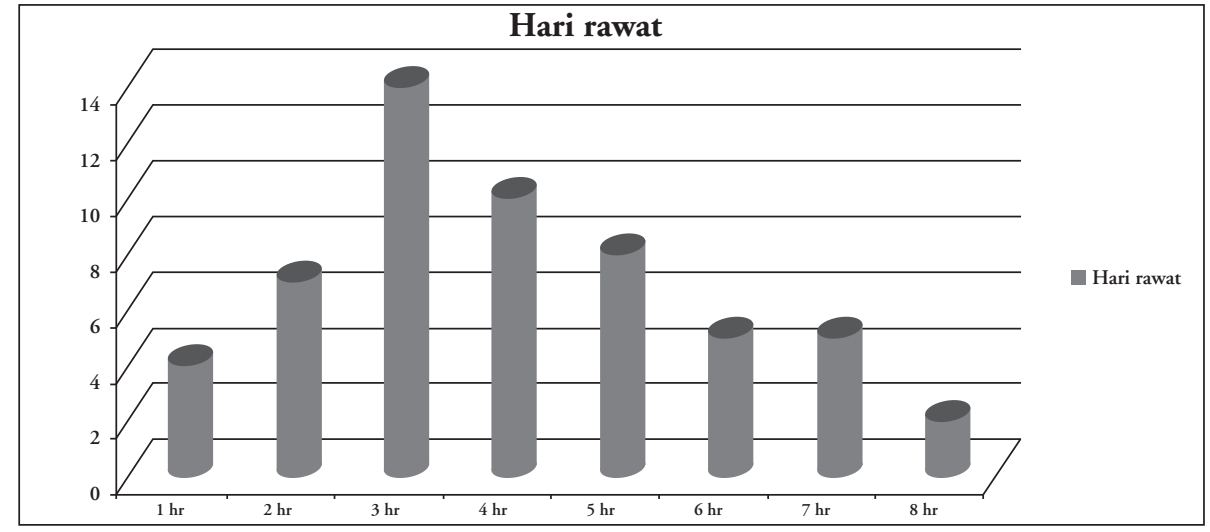

Gambar 3. Lamanya hari rawat pasien asma 
sebanyak 14 pasien $(25,4 \%)$.

Pada Gambar 4 menunjukkan pasien yang terbanyak dirawat dengan diagnosis asma bronkial episodik jarang adalah sebesar 43 pasien $(78,18 \%)$.

\section{Diagnosis}

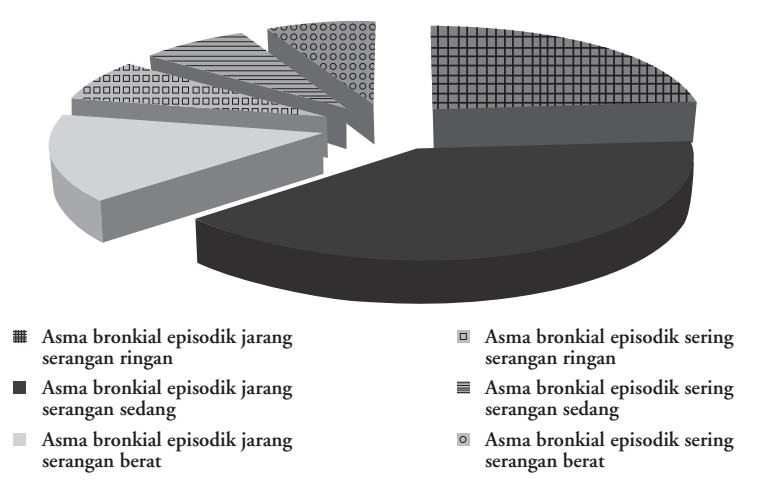

Gambar 4. Karakteristik pasien berdasarkan diagnosis saat dirawat

\section{Pembahasan}

Dalam studi kami 70 pasien yang didiagnosis dengan asma bronkial dari periode waktu bulan Januari 2007 sampai dengan Desember 2008 ditemukan 55 pasien dengan data yang lengkap, mulai dari jenis kelamin, usia, status gizi, lama pengobatan, dan diagnosis yang ditegakkan.

Pada penelitian kami diperoleh kejadian asma bronkial pada anak yang dirawat di ruang perawatan BLU RSUP. Prof. Dr. R.D. Kandou, Manado. Dari penelitian ini, pasien terbanyak adalah anak laki-laki (52\%). Noal $\mathrm{dkk}^{9}$ dalam penelitiannya melaporkan bahwa kejadian asma menurut jenis kelamin adalah tidak jelas. Walaupun demikian, ada penelitian lain yang melaporkan kejadian asma dan jenis kelamin terdapat hubungan yang signifikan, dimana disebutkan bahwa kejadian asma lebih sering terjadi pada anak laki-laki pada masa kanak-kanak. ${ }^{10}$

Pada penelitian kami ditemukan sebagian besar memiliki status gizi yang baik. Dari penelitian lain ditemukan bahwa kejadian anak-anak dengan obesitas memiliki kecenderungan mengalami kejadian asma kelompok usia 7-17 tahun. ${ }^{11}$ Dilaporkan juga adanya obesitas pada populasi umum rujukan anak-anak dengan asma. ${ }^{12}$ Belum didapatkan data mengenai hubungan kejadian asma dengan gizi baik.

Pada kriteria usia pada kejadian asma dalam penelitian ini ditemukan bahwa sebagian besar pada usia 7-9 tahun. Ini sesuai dengan penelitian yang dilakukan oleh Mary dkk, ${ }^{13}$ menyebutkan manifestasi asma pada usia 6-8 tahun. Ada juga studi terbaru di Skandinavia yang melaporkan terjadinya peningkatan insiden asma pada usia 10 tahun. ${ }^{14}$ Kejadian asma bronkial ini dapat dimulai pada usia berapa pun, tetapi kebanyakan anak memiliki gejala pertama mengalami asma pada usia 5 tahun. ${ }^{15}$

Pada penelitian kami didapatkan lama hari rawat sebagian besar pada pasien adalah 3 hari rawat inap, dengan waktu rawat inap rata-rata 4 hari. Penelitian lain juga melaporkan, menggunakan data 1994-1996 NHIS menemukan bahwa hari rawat 3,7 hari per anak menurut laporan orangtua anak yang mengalami asma. 16

Keterbatasan pada penelitian kami disebabkan karena keterbatasan data yang diperoleh dari rekam medis dan pemeriksaan penunjang untuk menilai terhadap berat ringannya asma bronkial belum dapat diterapkan sepenuhnya. Sebagai kesimpulan pada penelitian ini, asma bronkial terutama ditemukan pada anak laki-laki. Anak-anak dengan serangan asma bronkial episodik jarang yang paling sering didiagnosis, dengan lama rawatan 3 hari dan dengan rata-rata rawatan 4 hari, dan kebanyakan pasien asma memiliki status gizi yang baik, dengan sebagian besar pasiennya berusia 7-9 tahun.

\section{Kesimpulan}

Berdasarkan penelitian ini, asma terbanyak pada anak laki-laki. Status gizi pada umumnya baik dan terdapat leukositosis pada kebanyakan hasil pemeriksaan laboratorium. Asma episodik sedang adalah diagnosis yang paling banyak dijumpai.

\section{Daftar pustaka}

1. Santosa H. Asma bronkial. Dalam: Akib AAP, Matondang CS, penyunting, Buku ajar alergi imunologi anak, Jakarta: BP IDAI; 1996.h.179-99.

2. UKK Pulmonologi PP IDAI. Konsensus nasional asma anak, tata laksana jangka panjang. Bali, UKK 
Pulmonologi IDAI, 2002.

3. Supriyatno HB. Diagnosis dan penatalaksanaan terkini asma pada anak. Maj Kedok Indones, Jakarta. 2005;55:h.237-40.

4. Rahajoe N. Deteksi dan penanganan jangka panjang asma pada anak. Dalam : Setyanto DB, Manajemen kasus respiratorik anak dalam praktek sehari-hari. Edisi ke-2.Jakarta: Yayasan Penyantun Anak Asma Indonesia Suddhaprana;2007.h.95-108.

5. Boguniewich M, Leung DYM. Asthma. Dalam : Hay WW, Hayward AR, Levin MJ, Sondheimer JM, peyunting, Current Pediatric Diagnosis and Treatment. Edisi ke-15 New York : Lange Medical Books/McGrawHill, 2001: h.939-48.

6. Bierman CW, Pearlman DS. Asthma. Dalam: Chernick V, Kendig EL, peyunting, Kendig's Disorder of the Respiratory Tract in Children. Edisi ke-5. Philadelphia: WB Saunders, 1990: h.557 - 601.

7. Kartasasmita CB. Epidemologi asma anak. Dalam: Rahajoe NN, Supriyatno B, Setyanto DB. Buku ajar respirologi anak. Edisi pertama. Jakarta: Ikatan Dokter Anak Indonesia;2008.h.71-84.

8. Nataprawira HMD. Diagnosis asma pada anak. Dalam: Rahajoe NN, Supriyatno B, Setyanto DB. Buku Ajar Respirologi Anak. Edisi pertama. Jakarta: Ikatan Dokter Anak Indonesia;2008.h.115-9.

9. Noal RB, Menezes AMB, Macedo SEC, Dumith SC. Childhood body mass index and risk of asthma in adolescence: a systematic review. Epidemiology Postgraduate Program, Federal University of Pelotas, Pelotas, Brazil;2010.

10. Bjornson CL, Mitchell I. Gender differences in asthma in childhood and adolescence. J Gend Specif Med 2000;8:57-61.

11. Ahmad N, Biswas S, Bae S, Meador KE, Huang R, Singh KP. Association between obesity and asthma in US children and adolescents. J Asthma 2009;46:642-6.

12. Ross KR, Hart MA, Isser SA, Kibler AMV, Johnson NL, Rosen CLMD 1, dkk.. Obesity and obesity related co-morbidities in a referral population of children with asthma. Pediatr Pulmonol 2009; 44:877-84.

13. Klinnert M, Nelson HS, Price MR, Adinoff AD,Leung DY, Mrazek AD. Onset and persistence of childhood asthma: Predictors from infancy. Pediatrics 2001;108:69.

14. Nazario B. Asthma in children: Symptoms and risk factors. Asthma Health Center.. Didapat dari: www. webmd.com/asthmalchildren Diakses tanggal 02 Januari 2011.

15. Wang LY, Zhong Y, Wheeler L. Direct and indirect costs of asthma in school-age children. Preventing chronic disease CDC.2005;2:1.

16. DeFrances CJ Cullen KA, Kozak LJ. National Hospital Discharge Survey: 2005 Annual Summary with Detailed Diagnosis and Procedure Data. National Center for Health Statistics. Vital Health Statistics 2007;12:16 